\title{
Peningkatan Kesehatan Anak Usia Dini dengan Penerapan Perilaku Hidup Bersih dan Sehat (PHBS) di TK Kecamatan Candi Sidoarjo
}

\author{
Choirun Nisak Aulina ${ }^{1^{*}}$, Yuli Astutik ${ }^{2}$ \\ ${ }^{1}$ Prodi PG. PAUD FKIP Universitas Muhammadiyah Sidoarjo \\ ${ }^{2}$ Prodi Pendidikan Bahasa Inggris FKIP Universitas Muhammadiyah Sidoarjo \\ Email: lina@umsida.ac.id ${ }^{1}$,yuliastutik@umsida.ac.id ${ }^{2}$
}

\begin{abstract}
ABSTRAK
Tujuan kegiatan pengabdian kepada masyarakat ini adalah untuk meningkatkan pengetahuan guru dan orang tua tentang pentingnya Perilaku Hidup Bersih dan Sehat (PHBS). Perilaku hidup bersih dan sehat di sekolah merupakan perilaku yang di lakukan oleh siswa, guru dan masyarakat lingkungan sekolah atas kesadaran diri untuk mencegah penyakit, meningkatkan kesehatannya, serta mewujudkan lingkungan sehat. Kegiatan pengabdian ini di laksanakan di TK Aisyiyah 6 dan TK Riadhus Sholihin kecamatan Candi Sidoarjo. Metode dalam pelaksanaan kegiatan pengabdian yang dilakukan guna menyelesaikan permasalahan yang ada pada sekolah mitra berupa 1) Workshop tentang mengintegrasikan penerapan PHBS dalam kegiatan pembelajaran, 2) kegiatan parenting tentang makanan sehat bagi anak. Hasil dari kegiatan pengabdian ini berupa peraturan sekolah yang memuat tentang delapan indikator penerapan PHBS sekolah, terjadwalnya lima kegiatan penunjang penerapan PHBS sekolah, serta anak-anak tidak jajan sembarangan.
\end{abstract}

Kata Kunci: Perilaku Hidup Bersih dan Sehat (PHBS), Taman Kanak-Kanak, Siswa , Guru dan masyarakat lingkungan sekolah.

\section{ABSTRACT}

The purpose of this community service is to increase the knowledge of teachers and parents about the importance of Clean and Healthy Behaviour (PHBS). Clean and healthy behavior is also a set of behaviours practiced by learners, teachers and the school environment community on the basis of awareness so that independently able to prevent disease, improve health, and play an active role in creating a healthy environment. This community service activity is carried out in kindergarten of Aisyiyah 6 and kindergarten of Riadhus Sholihin at Kecamatan Candi Sidoarjo. The Method used in implementing this community service undertaken to solve the existing problems for those partner schools, such as 1) Workshop on integrating the implementation of Clean and Healthy Behaviour (PHBS) in learning activities, 2) parenting activities about healthy food for children. The result of this community service activity is a school regulation which contains about eight indicators of school PHBS implementation, scheduling five supporting activities of school PHBS implementation, and children not snacking haphazardly.

Keywords: Clean and Healthy Behaviour (PHBS), Kindergarten, Students, Teachers and school environment community 


\section{PENDAHULUAN}

Kesehatan merupakan kondisi dimana kita berada jauh atau terbebas dari penyakit. Kesehatan menjadi salah satu faktor penting dalam upaya pembangunan Sumber Daya Manusia (SDM), termasuk pendidikan. Oleh karena itu, menjadi hal yang wajar jika penjaminan kesehatan di Indonesia juga tertuang dalam UUD 1945 pasal $28 \mathrm{H}$ dan dijabarkan dalam UU RI No. 9 tahun 1960. Disahkannya perundangan tersebut, maka dapat dikatakan bahwa negara menjamin seluruh warganya tidak terkecuali bagi anak usia dini untuk memperoleh hak asasinya dalam mendapatkan pelayanan kesehatan .

Salah satu upaya untuk meningkatkan kualitas Sumber Daya Manusia sejak dini adalah dengan memberikan pelayanan pendididik pada ana usia dini. Anak usia dini berada pada masa perkembangan dan pertumbuhan anak sehingga sangat potensial untuk peletakan nilai-nilai. Disamping itu, pada usia tersebut anak rentan terserang penyakit. Hal ini di karenakan kebersihan makanan anak seringkali tidak terkontrol sehingga sangat rentan terhadap penularan bakteri dan virus atau biasa di sebut dengan food borne diseases. Food borne disease adalah suatu penyakit karena adanya virus atau bakteri yang masuk ke dalam tubuh manusia melalui proses pencernaan makanan, seperti cholera, helminthic infections (kecacingan), Dysenter (disentri), dan lain-lainnya (Barakki etal.,2005). Sebagaimana hasil penelitian Kesehatan Dasar (Riskesdas) tahun 2010 menunjukkan bahwa prevalensi kejadian diare di Indonesia sekitar 42,2\%. Pada anak usia sekolah (5-14 tahun), kejadian diare yaitu sebesar 9,0\%. Typhoid pada kelompok anak usia sekolah menempati prevalensi tertinggi dibandingkan semua kelompok usia yang ada, yaitu sebesar 1,9\% (Sholikhah, dkk 2013). Hal serupa juga di sampaikan oleh Miller dan Arlianti (2009: 2),banyak penyakit yang diderita anak-anak pada masa awal pertumbuhannya (0-5 tahun) dapat muncul kembali pada masa sekolah, terutama di awal-awal sekolah (6-8 Tahun). Usia balita merupakan usia rawan yang rentan akan penyakit. Hal ini karena aktivitas anak sangat tinggi, terutama dalam kegiatan bermain. Anak-anak kurang memahami arti pentingnya perilaku hidup bersih dan sehat.

Berdasarkan pendapat dari Organisasi Kesehatan Dunia atau WHO (1992: 1-7), faktor yang mempengaruhi kesehatan meliputi benda hidup, benda mati, peristiwa alam, faktor lingkungan buatan manusia, keturunan, dan perilaku. Hal serupa juga disampaikan oleh Blum bahwa faktor yang mempengaruhi kesehatan meliputi lingkungan, perilaku, pelayanan kesehatan, dan hereditas (Soekidjo Notoatmodjo, 2007). Keduanya menyatakan bahwa faktor perilaku yang dalam hal ini berupa tindakan memiliki pengaruh terbesar setelah faktor lingkungan 
terhadap derajad kesehatan setiap individu.

Mengingat pentingnya

kesehatan dalam pembangunan SDM, karakteristik anak usia dini dan besarnya peranan perilaku terhadap tingkat kesehatan, maka penggalakkan pola hidup sehat pada tatanan siswa Taman Kanak-kanak sangat diperlukan. Sebagai upaya untuk meningkatkan atau mempertahankan kesehatan secara optimal seorang individu tercermin dari usaha dalam menerapkan pola hidup sehat setiap harinya sebagai gambaran perilakunya. WHO (1992: 7-17) menyebutkan bahwa faktor yang mempengaruhi tidakan seseorang adalah pikiran dan perasaan, orang yang berarti , sumber daya alam yang ada serta budaya.

Perilaku Hidup Bersih dan Sehat (PHBS) adalah semua perilaku kesehatan yang dilakukan atas kesadaran sehingga anggota keluarga atau keluarga dapat menolong dirinya sendiri di bidang kesehatan dan dapat berperan aktif dalam kegiatan kegiatan kesehatan dan berperan aktif dalam kegiatan-kegiatan kesehatan di masyarakat (Depkes RI, 2007). Pembinaan lingkungan sekolah sehat memungkinkan siswa dapat mencapai derajad kesehatan yang setinggitingginya untuk mencapai proses belajar yang maksimal (Kemendikbud, 2012: 29). Sekolah sehat harus memiliki lingkungan yang mendukung pembelajaran. Program ini menekankan pada aspek lingkungan yang meliputi lingkungan fisik dan non fisik (Kemendikbud, 2012: 29-36).

Sejalan dengan hal tersebut, idealnya pola hidup sehat siswa TK di kecamatan Candi Sidoarjo baik. Namun, berdasarkan studi pendahuluan yang dilakukan TK Riadhus Sholihin yang berada di desa Kalipecabean kecamatan Candi. Desa Kalipecabean merupakan desa ujung timur kecamatan Candi yang mana masyarakatnya kebanyakan petani tambak bagi laki-laki dan buruh pabrik bagi perempuannya. Karena dekat dengan tambak maka udara yang ada di kawasan ini juga agak lebih panas di banding dengan daerah lain di kecamatan Candi. TK Riadhus Sholihin ini kondisinya tidak jauh berbeda dengan TK Aisyiyah 6 Durung Bedug. Pemahaman masyarakat dalam hal menjaga kebersihan sangatlah minim. Hal ini terlihat juga di lingkungan sekolah yang masih minimnya fasilitas tempat membuang sampah karena masih terbiasa membuang sampah di sembarang tempat, mindset yang ada selama ini sampah itu akan di bersihkan dengan aktivitas rutin yakni menyapu setiap pagi dan sore layaknya orang desa pada umumnya, Fasilitas kamar mandi yang masih belum ramah anak yakni kotor dan gelap sehingga anak-anak kadang memilih pulang dari pada buang hajat di sekolah. Fasilitas cuci tangan masih menggunakan ember isi air yang pemakaiannya secara bergantian sehingga rentan kuman karena anak yang cuci tangan terakhir pasti air 
lebih kotor di banding anak-anak sebelumnya. Peraturan untuk membawa bekal makanan bagi siswa masih belum di laksanakan. Anakanak istirahat sekolah jajan sembarangan di luar pagar, yang mana tingkat kebersihan makanan atau jajanan tersebut belum terjamin. Hal ini karena pemahaman orang tua akan pentingnya membawa bekal dari rumah untuk menjaga kebersihan makanan anak-anak masih sangat minim.

Berdasarkan permasalahan yang ada di sekolah mitra, maka dilakukan pengabdian kepada masyarakat dengan melakukan penerapan Perilaku Hidup Bersih dan Sehat (PHBS) di TK kecamatan Candi Sidoajo

\section{METODE PELAKSANAAN}

Dalam pelaksanaan Program Kemitraan Masyarakat (PPM) penerapan pedoman PHBS di Taman Kanak-kanak kecamatan Candi Sidoarjo. Berikut metode pendekatan yang dilakukan dalam program ini adalah :

1. Pelatihan bagi guru tentang penerapan PHBS bagi anak, kegiatan ini di lakukan sebagai penguatan program PHBS bagi guru-guru di kedua sekolah Mitra. Dalam pelatihan ini nanti tidak hanya pemaparan materi PHBS namun juga aplikasi kegiatan pengembangan PHBS bagi peserta didik sesuai dengan konsep pembelajaran anak usia dini.

2. Workshop penyusunan program PHBS sesuai dengan pembelajaran di TK, kegiatan ini dilakukan untuk menyusun kurikulum terkait program PHBS di sekolah mitra. Sehingga semua indikator pelaksanaan PHBS sekolah dapat terintegrasi dalam proses pembelajaran.

3. Parenting bagi wali murid TK mitra tentang penerapan PHBS di sekolah

4. Implementasi delapan indikator penerapan PHBS sekolah serta lima kegiatan penunjang.

5. Refleksi dan tindak lanjut, ke

6. Kegiatan ini merupakan refleksi dari implementasi penerapan PHBS di sekolah berikut keterlibatan wali murid dan warga sekitar sekolah.

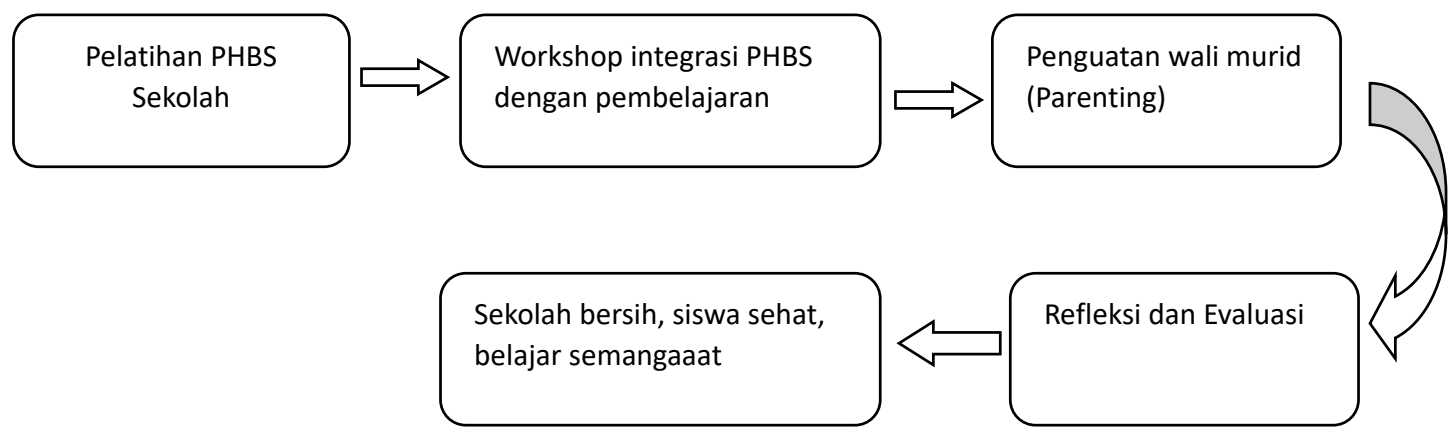

Gambar 1. Prosedur pelaksanaan pengabdian 
Program pengabdian kepada masyarakat ini dilaksanakan di TK Riadhus Shoilihin Kalipecabean dan TK Aisyiyah 6 Durung Bedug Kecamatan Candi Sidoarjo dengan kurun waktu selama 6 bulan dari bulan September 2017 sampai dengan Pebruari 2018.

\section{Hasil Dan Pembahasan}

\section{Mengintegrasikan program PHBS} dalam kegiatan pembelajaran

Dalam rangka mengintegrasikan program penerapan Perilaku Hidup Bersih dan Sehat (PHBS) di sekolah mitra, maka dilaksanakan workshop dengan guru selama dua hari yang dilaksanakan pada hari Senin-selasa, 15-16 Januari 2018. Kegiatan ini dilaksanakan sebagai upaya untuk menyamakan persepsi guru terkait pentingnya penerapan PHBS disekolah serta penjabaran indikator penerapan PHBS seholah. Selain ini dalam kegiatan ini selain menyamanakn pemahaman tentang PHBS, guru juga menyusun implementasi tiap indikator dalam kegiatan di sekolah baik tertuang secara terjadwal sebagai kegiatan rutin, pembiasaan maupun di peraturan. Selanjutnya juga memperaktekkan beberapa implentasi indikator PHBS seperti gerakan cuci tangan yang benar sesuai anjuran WHO, cara buang air besar dan kecil yang benar, cara mengukur berat badan dan tinggi badan serta menganalisisnya menggunakan kurva pertumbuhan.
Indikator yang digunakan untuk mengukut tingkat keterlaksanaan PHBS di sekolah yaitu : 1) Mencuci tangan dengan air yang mengalir dan menggunakan sabun, 2) Mengkonsumsi jajanan sehat di kantin sekolah, 3) Menggunakan jamban yang bersih dan sehat, 4) Olahraga yang teratur dan terukur, 5) Memberantas jentik nyamuk, 6) Tidak merokok di sekolah, 7) Menimbang berat badan dan mengukur tinggi badan setiap bulan, 8) Membuang sampah pada tempatnya. Dari ke delapan indicator tersebut maka dijabarkan sebagai berikut.

1) Mencuci tangan dengan air yang mengalir dan menggunakan sabun

Untuk mengimplementasikan indikator ini, yang pertama dilakukan dengan menyediakan tempat cuci tangan dengan air mengalir di luar kelas sehingga mudah di jangkau anak-anak. Selanjutnya anak-anak di biasakan selalu cuci tangan menggunakan sabun setiap selesai melakukan tugas, sebelum dan sesudah makan, serta terbiasa segera cuci tangan setiap kali tangan kotor.

2) Mengkonsumsi jajanan sehat di kantin sekolah

Kedua sekolah mitra tidak memiliki kantin sekolah, maka untuk implementasi pada indikator ini dengan mewajibkan anak-anak membawa bekal makanan dari rumah ke sekolah. Dengan catatan makanan yang di bawah anak-anak sesuai ketentuan yakni tidak boleh makanan instant atau snack yang mengandung 
5P yakni penyedap rasa, pemanis, pengawet, pengenyal, dan pengental. Hal ini bertujuan agar makanan yang dikonsumsi anak-anak mengandung nilai gizi seimbang. Dari hasil kegiatan ini anak-anak sudah tidak lagi jajan sembarangan di penjual depan pagar sekolah, anak-anak sudah mulai berkomentar jika ada temennya membawa makanan mengandung pewarna yang sangat mencolok, yang ada saosnya atau jika temannya membawa snack yang mengandung penyedap.

3) Menggunakan jamban (kamar kecil) yang bersih dan sehat

Kamar kecil yang ada di sekolah setiap hari di bersihkan serta terjadwal dua hari sekali harus di kuras. Anak-anak juga di ajarkan bagaimana cara buang air kecil maupun air besar yang benar. Selain itu anak-anak juga di biasakan membasahi lantai kamar kecil dulu sebelum buang air kecil serta selalu menyiram jika selesai buang air kecil maupun air besar sehingga lantai kamar kecil tidak bau.

4) Olahraga yang teratur dan terukur

Kegiatan olah raga secara terjadwal di laksanakan senam dan juga jalan-jalan sekitar lingkungan sekolah setiap hari Sabtu. Namun selain senam, anak-anak setiap hari sebelum kegiatan materi pagi juga selalu di lakukan kegiatan olah tubuh misalnya berjalan di atas papan titian, melempar dan menangkap bola. Kegiatan olah raga ini diharapkan dapat menjaga kesehatan serta kebugaran tubuh anak dan guru sehingga tidak mudah sakit.

5) Memberantas jentik nyamuk

Sebagai upaya untuk memberantas jentik di lingkungan sekolah maka di lakukan pengurasan bak kamar mandi setiap dua hari sekali, selalu melakukan pengecekan pada wadah pembuangan air di kulkas, pot bunga serta barang-barang bekas di sekitar lingkungan sekolah. Selain kegiatan tersebut, sekolah juga mengikuti kegiatan foging/ pengasapan yang dilakukan puskesmas secara berkala. Kegiatan ini di harapkan dapat meminimalisir perkembangan jentik-jentik nyamuk sehingga tidak menyebarkan penyakit baik malaria, demam berdarah maupun yang lain.

6) Tidak merokok di sekolah

Lingkungan sekolah mengembangkan kawasan tanpa rokok/kawasan bebas asap rokok. Sehingga baik walimurid atau tamu yang datang ke sekolah wajib mematuhi peraturan untuk tidak boleh merokok di kawasan sekolah.

7) Menimbang berat badan dan mengukur tinggi badan setiap bulan

Implementasi indikator ini adalah dilakukannya penimbangan berat badan anak serta pengukuran tinggi badan anak setiap hari Sabtu minggu ke empat setiap bulannya. Hasil penimbangan dan pengukuran di catat secara rutin serta di lakukan pengkajian apakah berat badan dan tinggi badan anak berada pada standart pertumbuhan normal atau 
sebaliknya. Hasil penimbangan dan pengukuran dibandingkan dengan standar berat badan dan tinggi badan menurut kurva pertumbuhan WHO sehingga diketahui apakah pertumbuhan anak berada pada garis normal atau tidak yang selanjutnya dapat di tindak lanjuti dengan pemberian catatan pada orang tua siswa dan juga rencana tindakan yang harus dilakukan guru di sekolah.

8) Membuang sampah pada tempatnya

Untuk mengimplementasikan indikator ini, guru mengintegrasikan dengan materi kegiatan sesuai tema yang ada. Hal ini di lakukan dengan berbagai metode baik melalui bercerita, bermain peran dan juga penyampaian secara langsung terkait anjuran membuang sampah pada tempatnya, akibat membuang sampah sembarangan serta kewajiban selalu membersihkan sampah yang berserakan. Selain itu guru memberikan contoh/teladan selalu membaung sampah di tempat yang telah disediakan. Guru menyediakan tempat sampah di beberapa tempat strategis sehingga mudah dijangkau oleh anak, misalnya setiap kelas satu tempat sampah, di luar kelas dekat teras/tempat bermain anak.

Selain delapan indikator tersebut, sekolah juga menerapkan beberapa kegiatan penunjang penerapan PHBS antara lain : 1) Memelihara rambut agar bersih dan rapi, 2) Memakai Pakaian Bersih dan Rapi 3) Memelihara Kuku Agar Selalu Pendek dan Bersih, 4) Memakai Sepatu Bersih dan Rapi, pemerikasaan empat kegiatan tersebut di lakukan secara rutin setiap Senin pagi. Guru mengecek apakah rambut anak terutama yang laki-laki terlalu panjang apa tidak, kemudian rambut bersih atau lepek tanda jarang keramas. Selanjutnya guru juga mengecek apakah kuku anak panjang dan kotor, jika iya maka guru kelas memotong kuku anak tersebut hal ini di lakukan agar anak bersih dan tidak mudah kena penyakit. Contohnya kuku tangan, jika kuku panjang dan kotor maka anak akan mudah sakit perut karena kuman yang ada di kukunya. Selanjutnya kegiatan penunjang yang ke 5) menggunakan air bersih untuk kebutuhan anak dan guru di kamar kecil maupun untuk kegiatan cuci tangan.

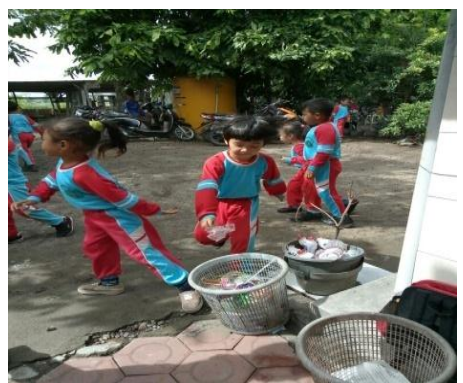

Gambar. 1 Terbiasa membuang sampah pada tempatnya 


\section{Meningkatkan pemahaman wali murid terkait makanan sehat}

Untuk

meningkatkan

pemahaman walimurid terkait makanan sehat untuk anak usia dini, maka dilaksanakan kegiatan parenting pada Kamis, 25 Januari 2018 dengan narasumber Yanik Puswanti, M.Keb. Kegiatan ini di hadiri walimurid kelompok A dan kelompok B sekolah mitra. Pada kegiatan ini di awali dengan sosialisasi pelaksanaan penerapan Perilaku Hidup Bersih dan Sehat (PHBS) di sekolah yang meliputi delapan indikator yakni : 1) Mencuci tangan dengan air yang mengalir dan menggunakan sabun, 2) Mengkonsumsi jajanan sehat di kantin sekolah, 3) Menggunakan jamban yang bersih dan sehat, 4)
Olahraga yang teratur dan terukur, 5) Memberantas jentik nyamuk, 6) Tidak merokok di sekolah, 7) Menimbang berat badan dan mengukur tinggi badan setiap bulan, 8) Membuang sampah pada tempatnya.

Selanjutnya dalam kegiatan ini nara sumber menyampaikan pentingnya pemilihan makanan sehat untuk anak. Makanan anak-anak harus bebas dari 5P yakni penyedap rasa, pemanis, pengawet, pengenyal, dan pengental. Hasil dari kegiatan parenting ini, orang tua wajib membawakan bekal makanan untuk anak-anak baik kelompok A maupun kelompok B sehingga anak-anak tidak lagi membeli jajanan sembarangan.
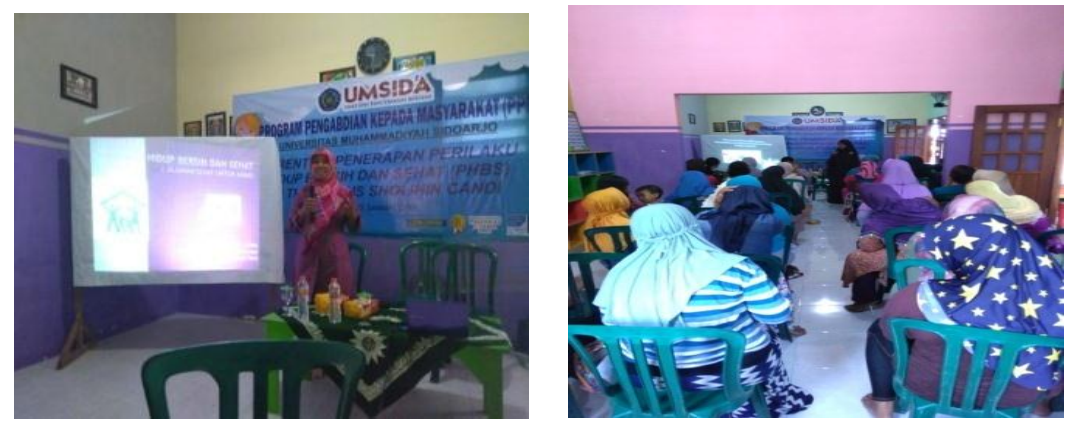

Gambar 2. Parenting makanan sehat

Kegiatan parenting mendapat respon yang sangat baik dari wali murid, hal ini terlihat dari antusiasnya peserta saat dibuka sesi tanya jawab. Mereka menanyakan terkait jajanan yang selama ini di jual di sekitar sekolah, cara pengolahan makanan yang sehat, serta praktek tujuh langkah cuci tangan yang benar sesuai dengan panduan WHO.

\section{SIMPULAN}

Berdasarkan hasil kegiatan pengabdian dapat disimpulkan bahwa perilaku hidup bersih dan sehat sangat penting untuk di terapkan pada anak 
usia dini. Kepala dan guru sekolah mitra menyatakan kegiatan ini sangat bermanfaat karena dapat meningkatkan kualitas kesehatan anak. Disamping itu dengan adanya kegiatan parenting terkait makanan sehat untuk anak juga sangat bermanfaat sehingga program kegiatan sekolah terutama tentang kewajiban anak membawa bekal dari rumah dan tidak jajan sembarangan di sekolah dapat terealisasi dengan baik karena meningkatnya pemahaman orang tua tentang pentingnya menerapkan PHBS.

\section{DAFTAR PUSTAKA}

Barakki Negga, Abera Wodajo, Mussie Abera, Lemessa Oljira, Habtamu Mitiku, Seyoum Mengistu, Fekade Ketema, 2005. Food-Borne Diseases, Haramaya niversity, USAID In Collaboration With The Ethiopia Public Health Training Initiative, The Carter Center, The Ethiopia Ministry of Health, and The Ethiopia Ministry of Education. Module. Ethiopia.

Joy Miller Del Rosso dan Rina Arlianti. (2009). "Investasi Kesehatan dan Gizi Sekolah di Indonesia". Diambil dari https://issuu.com/worldbank.ind onesia/docs/investasi untuk kes ehatan pada 03 Januari 2018 pukul 09.15

Kemendikbud. (2012). Pedoman Pelaksanaan UKS di Sekolah. Jakarta: Kemendikbud.
Kesehatan. Jakarta: Depkes RI. 2. Depkes RI, 2002, Panduan Manajemen PHBS Menuju Kabupaten/Kota Sehat. Pusat Promosi Kesehatan. Jakarta: Depkes RI.

Notoatmodjo, S. 2007. Promosi Kesehatan dan Ilmu Perilaku, Jakarta. Rineka Cipta

Organisasi Kesehatan Dunia atau WHO. (1992). Pendidikan Kesehatan: Pedoman Pelayanan Kesehatan Dasar. Bandung: ITB dan Udayana

Sholikhah, Hidayad Heny dan Florentina Sustin, Gambaran Perilaku Hidup Bersih Dan Sehat Tentang Food Borne Disease Pada Anak Usia Sekolah Di Sdn

Babat Jerawat I Kecamatan Pakal Kota Surabaya ( Description of Clean and Healthy Behavior of Food Borne Disease Among by School Children Age in Babat Jerawat I Elementary School, District Pakal Surabaya), Surabaya : Buletin Penelitian Sistem Kesehatan - Vol. 16 No. 4 Oktober 2013: 351-362

Suyanto, Slamet. 2005 Konsep Dasar Pendidikan Anak Usia Dini. Jakarta: Depdiknas Dirjen Pendidikan Tinggi. 